九州大学学術情報リポジトリ

Kyushu University Institutional Repository

\title{
A Study of Density for Pullulan/Ionic Liquid Solutions
}

$\mathrm{Hu}$, Hao

Interdisciplinary Graduate School of Engineering Sciences, Kyushu University

Takada, Akihiko

Institute for Materials Chemistry and Engineering, Kyushu University

Takahashi, Yoshiaki

Institute for Materials Chemistry and Engineering, Kyushu University

https://doi.org/10.5109/1440970

出版情報: Evergreen. 1 (1)，pp.14-19，2014-03. 九州大学グリーンアジア国際リーダー教育センター バージョン：

権利関係 : 


\title{
A Study of Density for Pullulan/Ionic Liquid Solutions
}

\author{
Hao $\mathrm{Hu}^{*}{ }^{*}$, Akihiko Takada ${ }^{2}$, Yoshiaki Takahashi ${ }^{2}$ \\ ${ }^{1}$ Interdisciplinary Graduate School of Engineering Sciences, Kyushu University \\ ${ }^{2}$ Institute for Materials Chemistry and Engineering, Kyushu University \\ *Author to whom correspondence should be addressed, E-mail: huhao009@hotmail.com
}

(Received January 10, 2014; accepted March 7, 2014)

\begin{abstract}
Empirical relationships were obtained at temperatures $10-80{ }^{\circ} \mathrm{C}$ between density $\rho$ and mass concentration $C(\mathrm{wt} \%)$ of pullulan, which was used as a standard polymer in aqueous solutions containing two representative ionic liquids, 1-butyl-3-methylimidazolium chloride and 1-ethyl-3-methylimidaolium acetate. Water content effect on $\rho$ was also examined. Pullulan was successfully dissolved into these ionic liquids without degradation, confirmed by the recovered samples. This indicates that pullulan is a suitable standard for ionic liquid soluble polymers. The empirical relationships provide easy conversion of $C$ to concentration $c\left(\mathrm{~g} / \mathrm{cm}^{3}\right)$, which is essential for systematic studies of properties of pullulan in ionic liquids.
\end{abstract}

\section{Introduction}

Ionic liquids (IL) are low melting point organic salts that exist in the liquid state at around room temperature. ${ }^{1)}$ Because of their unique characteristics such as extremely low vapor pressure, thermal stability, and high ionic conductivity, ILs have been widely used in many fields involving organic and inorganic synthesis, ${ }^{2), 3)}$ catalysis, ${ }^{2}$ physical chemistry, ${ }^{4), 5}$ and advanced materials. ${ }^{6)-8)}$ Imidazolium-based ILs has been reported to dissolve cellulose and other polysaccharides, which are insoluble in conventional solvents. To date, reports have focused on 1-butyl-3-methylimidazolium chloride $(\mathrm{BmimCl}){ }^{9)}$ 1-allyl-3-methylimidazolium chloride $(\mathrm{AmimCl}){ }^{10)}$ and 1-ethyl-3-methylimidaolium acetate (EmimAc) as new environmentally friendly solvents for cellulose. ${ }^{11)}$ Ionic liquid solutions of cellulose are expected to lead new materials. ${ }^{12,13)}$ In addition, rheological studies of polymers using ILs as solvents have been reported. ${ }^{14-17)}$

Basic understanding of synthetic polymer properties in dilute solution, in close relationship with molecular characterization, has contributed to the progress of polymer science and industry. Standard samples with narrow molecular weight distributions (MWD) have played an important role in this progress. Physical property investigations of so-called insoluble natural polymers in dilute IL solutions are expected to contribute to advances in the science and technology of these polymers.

The linear polysaccharide pullulan consists of maltotriose units called $\alpha-1,4$ and $\alpha$-1,6-glucan. Because this polysaccharide is a water soluble polymer with well-understood properties in aqueous solutions, ${ }^{18-20)}$ pullulan samples fractionated by molecular weight have been used as standard polymers for water soluble polymers. In addition, as reported in this study, its solubility into ILs makes it a potential candidate as a standard sample for IL soluble polymers.

Accurate evaluations of physical properties in solution rely on empirical relationships between the density and concentrations in $\mathrm{wt} \%$ and $\mathrm{g} / \mathrm{cm}^{3}$. Note that, because ILs are glass forming liquids, their density may depend more strongly on temperature compared with conventional solvents. Moreover, polysaccharides exhibit higher densities than synthetic polymers. Therefore, the density of pullulan should not be assumed to be $1 \mathrm{~g} / \mathrm{cm}^{3}$, as seen in many recent studies on polymer solutions. In this study, pullulan was dissolved into $\mathrm{BmimCl}$ and EmimAc without sample degradation. The densities of sample solutions were determined for concentrations of up to $c a$. $16 \mathrm{wt} \%$. The influence of water content on the density was also examined to account for the effects of residual water and moisture adsorption in the ILs.

\section{Experimental section}

\subsection{Materials}

EmimAc (purity: $97 \%$, water content: $\leq 0.5 \%$ ) was purchased from Sigma-Aldrich and used as received. $\mathrm{BmimCl}$ was synthesized and purified according to previously reported methods with slight modifications. ${ }^{1,21)}$ Toluene was used as solvent in this synthesis. Pullulan (about $100 \mathrm{~kg} / \mathrm{mol}$ ) was used as received from Hayashibara Co., Ltd. Before solution preparation, all pullulan samples and ILs were dried in vacuo at $60^{\circ} \mathrm{C}$ for $12 \mathrm{~h}$.

\subsection{Sample preparation}

According to a preliminary study ${ }^{22)}$ homogeneous pullulan/ $\mathrm{BmimCl}$ solutions cannot be prepared below $80{ }^{\circ} \mathrm{C}$. On the other hand, intrinsic viscosity measurements of aqueous solution of pullulan recovered 


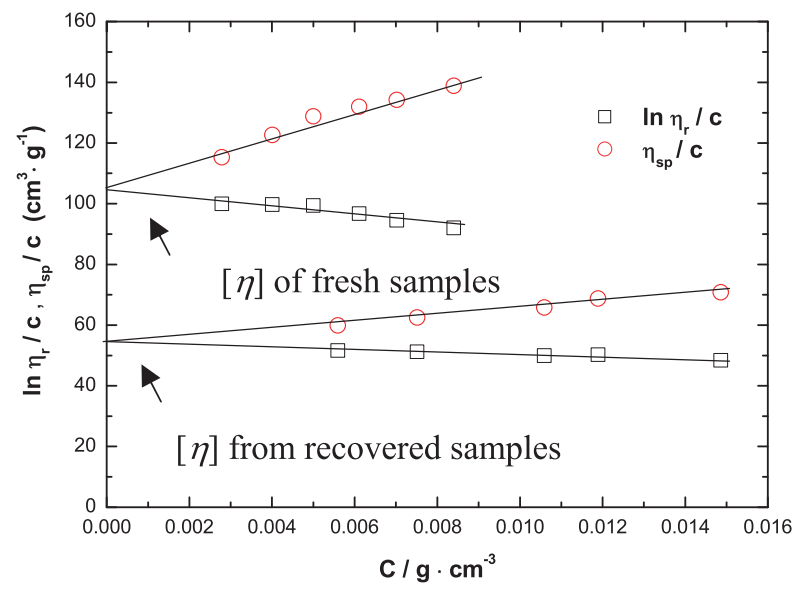

Fig. 1 Intrinsic viscosities $[\eta]$ of pullulan in aqueous solution from recovered samples prepared at $80^{\circ} \mathrm{C}$ and from fresh samples.

from the $\mathrm{BmimCl}$ solution indicated that the sample underwent degradation and oxidation when the temperature exceeded $80{ }^{\circ} \mathrm{C}$ (Figure 1). Therefore, pullulan solution in $\mathrm{BmimCl}$ was prepared by the following method. An aqueous solution of pullulan was first prepared and mixed with a prescribed amount of $\mathrm{BmimCl}$. Next, the sample solution was dried at $60{ }^{\circ} \mathrm{C}$ for $72 \mathrm{~h}$ in vacuo to remove the water. Water contents of sample solutions were measured by Karl-Fischer titration to ensure that they were below $2 \mathrm{wt} \%$. Pullulan solutions in EmimAc were prepared by direct dissolution at $60{ }^{\circ} \mathrm{C}$ in vacuo for $72 \mathrm{~h}$. The solutions were clear and their water contents did not exceed $1 \mathrm{wt} \%$. The intrinsic viscosities $[\eta]$ of pullulan amounted to 106.9 and 105.1 $\mathrm{cm}^{3} / \mathrm{g}$ in aqueous solutions of samples recovered from $\mathrm{BmimCl}$ and EmimAc, respectively. These values are in reasonable agreement with data obtained for the fresh sample $\left(105.3 \mathrm{~cm}^{3} / \mathrm{g}\right)$, confirming no sample degradation during dissolution.

\subsection{Density measurements}

Densities $\rho\left(\mathrm{g} / \mathrm{cm}^{3}\right)$ of pullulan $/ \mathrm{BmimCl}$ and pullulan/EmimAc solutions were measured for different concentrations under atmospheric pressure in a DMA 4500 Anton Parr density meter between 10.00 and $80.00{ }^{\circ} \mathrm{C}$. Temperatures were controlled within $\pm 0.05^{\circ} \mathrm{C}$ for each measurement. The uncertainty of the measurements was estimated to lower than $\pm 1 \times 10^{-4}$ $\mathrm{g} / \mathrm{cm}^{-3}$. All the measured data are tabulated in Appendix I.

\section{Results and discussion}

\subsection{Density of pullulan in IL solutions}

Figures $2 \mathrm{a}$ and $2 \mathrm{~b}$ show the influence of concentration $C(\mathrm{wt} \%)$ on the densities of pullulan/ $\mathrm{BmimCl}$ and pullulan/EmimAc solutions, respectively. All solutions exhibited a linear increase in their densities with increasing concentration. Figures $3 \mathrm{a}$ and $3 \mathrm{~b}$ show the effect of temperature $T$ on the densities of pullulan/BmimCl and pullulan/EmimAc solutions, respectively. These plots indicated that densities increased linearly with decreasing temperature for all solutions. An empirical relationship between density and concentration was derived from these results as

$$
\rho=\alpha C+\rho_{0} \quad\left(\mathrm{~g} / \mathrm{cm}^{3}\right)
$$

where $\rho_{0}$ is the density of pure ILs and $\alpha$ is the prefactor. For all pullulan/IL solutions, $\alpha$ values are shown in Table 1. The uncertainties of $\alpha$ were estimated to be $\pm 2 \times 10^{-5}$ and $\pm 8 \times 10^{-5}$ for pullulan $/ \mathrm{BmimCl}$ and pullulan/EMimAc solutions, respectively. Therefore, equation (1) provides the density of any pullulan/IL solution in this concentration range. Furthermore, the concentration $\mathrm{c}$ in $\mathrm{g} / \mathrm{cm}^{3}$ was obtained using

$$
c=\rho C / 100\left(\mathrm{~g} / \mathrm{cm}^{3}\right)
$$

Temperature effects on density were complex near the glass transition temperature. However, between 10.00 and $80.00{ }^{\circ} \mathrm{C}$, the following linear relationship was obtained between density and temperature:

$$
\rho=b T+K \quad\left(\mathrm{~g} / \mathrm{cm}^{3}\right)
$$

where $K$ is the density at $0{ }^{\circ} \mathrm{C}$ and $b$ is the prefactor. Values of $b$ for several concentrations are listed in Table 2. The uncertainties of $b$ were estimated to be $\pm 5 \times 10^{-6}$ for both pullulan/BmimCl and pullulan/EMimAc solutions, respectively.

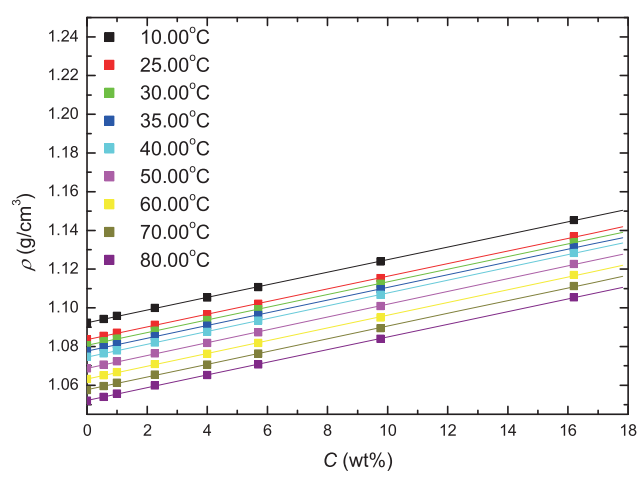

Fig. 2a Effect of concentration on the densities of pullulan/BmimCl solutions at different temperatures. 


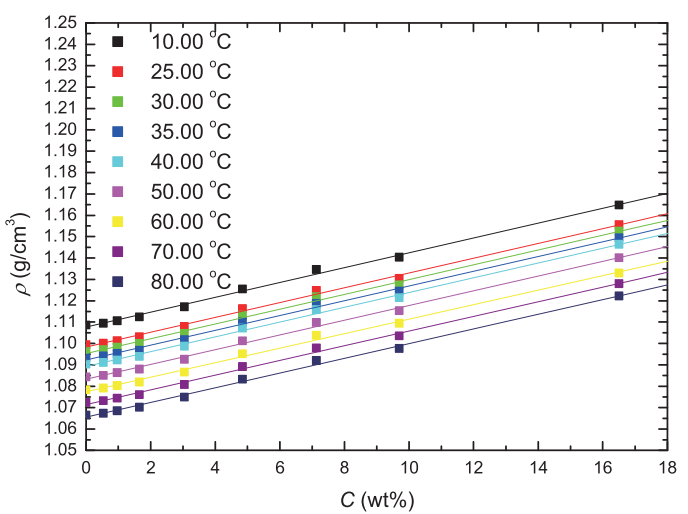

Fig. 2b Effect of concentration on the density of pullulan/EmimAc solution at different temperatures.

Table 1. Prefactor values $\alpha$ obtained using eq. (1) for pullulan/IL solutions from 10 to $80^{\circ} \mathrm{C}$.

\begin{tabular}{ccc}
\hline & \multicolumn{2}{c}{$\alpha$} \\
\cline { 2 - 3 } $\mathrm{T}$ & Pullulan/BmimCl & Pullulan/EmimAc \\
$10.00{ }^{\circ} \mathrm{C}$ & $3.25 \times 10^{-3}$ & $3.47 \times 10^{-3}$ \\
$25.00^{\circ} \mathrm{C}$ & $3.27 \times 10^{-3}$ & $3.46 \times 10^{-3}$ \\
$30.00{ }^{\circ} \mathrm{C}$ & $3.27 \times 10^{-3}$ & $3.46 \times 10^{-3}$ \\
$35.00{ }^{\circ} \mathrm{C}$ & $3.28 \times 10^{-3}$ & $3.46 \times 10^{-3}$ \\
$40.00{ }^{\circ} \mathrm{C}$ & $3.31 \times 10^{-3}$ & $3.46 \times 10^{-3}$ \\
$50.00{ }^{\circ} \mathrm{C}$ & $3.31 \times 10^{-3}$ & $3.45 \times 10^{-3}$ \\
$60.00{ }^{\circ} \mathrm{C}$ & $3.30 \times 10^{-3}$ & $3.39 \times 10^{-3}$ \\
$70.00{ }^{\circ} \mathrm{C}$ & $3.29 \times 10^{-3}$ & $3.44 \times 10^{-3}$ \\
$80.00{ }^{\circ} \mathrm{C}$ & $3.27 \times 10^{-3}$ & $3.44 \times 10^{-3}$
\end{tabular}

Table 2. Prefactor values $b$ obtained using eq. (3) for pullulan/IL solutions at different concentrations.

\begin{tabular}{rc}
\hline & $b$ \\
\cline { 2 - 2 } $0.00 \mathrm{wt} \%$ & Pullulan/BmimCl \\
$2.26 \mathrm{wt} \%$ & $-5.78 \times 10^{-4}$ \\
$5.71 \mathrm{wt} \%$ & $-5.72 \times 10^{-4}$ \\
$9.77 \mathrm{wt} \%$ & $-5.72 \times 10^{-4}$ \\
$16.22 \mathrm{wt} \%$ & $-5.74 \times 10^{-4}$ \\
$C$ & $-5.69 \times 10^{-4}$ \\
$0.00 \mathrm{wt} \%$ & Pullulan/EmimAc \\
$3.05 \mathrm{wt} \%$ & $-6.02 \times 10^{-4}$ \\
$4.85 \mathrm{wt} \%$ & $-6.03 \times 10^{-4}$ \\
$9.70 \mathrm{wt} \%$ & $-6.02 \times 10^{-4}$ \\
$16.53 \mathrm{wt} \%$ & $-6.05 \times 10^{-4}$ \\
& $-6.11 \times 10^{-4}$
\end{tabular}

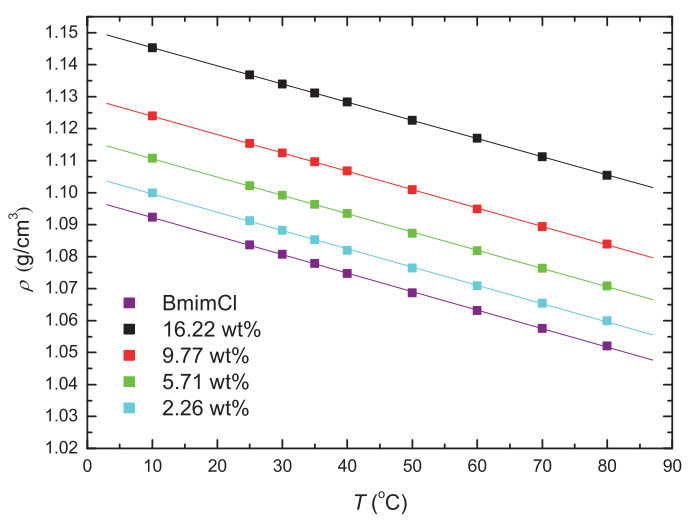

Fig. 3a Effect of temperature on the density of pullulan/BmimCl solutions at different concentrations.

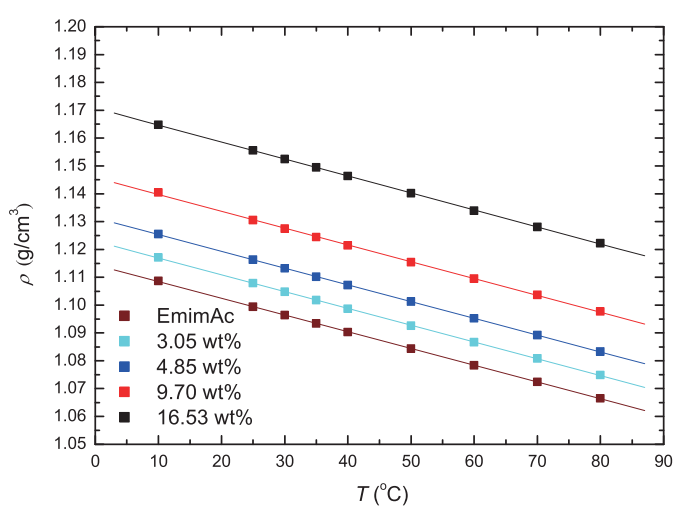

Fig. 3b Effect of temperature on the density of pullulan/EmimAc solutions at different concentrations.

\subsection{Influence of water content of the density of pullulan/IL solutions}

The influence of water content on $\rho$ was also discussed because ILs easily absorb moisture. The effect of water content $C_{w}(\mathrm{wt} \%)$ on the densities of pullulan/ $\mathrm{BmimCl}$ and pullulan/EmimAc solutions is shown in Figures 4 and 5 , respectively. For pullulan/ $\mathrm{BmimCl}$ solutions, the water content displayed little influence on the density below $6.6 \mathrm{wt} \%$. Because all pullulan/ $\mathrm{BmimCl}$ solutions contained less than $2 \mathrm{wt} \%$ water in this study, it can be assumed that water content does not affect their densities.

For pullulan/EmimAc solutions, the densities increased with increasing water content. In this study, however, $C_{w}$ values remained below $1 \mathrm{wt} \%$ for pullulan/EmimAc solutions. Therefore, the influence of water content was also negligible. 


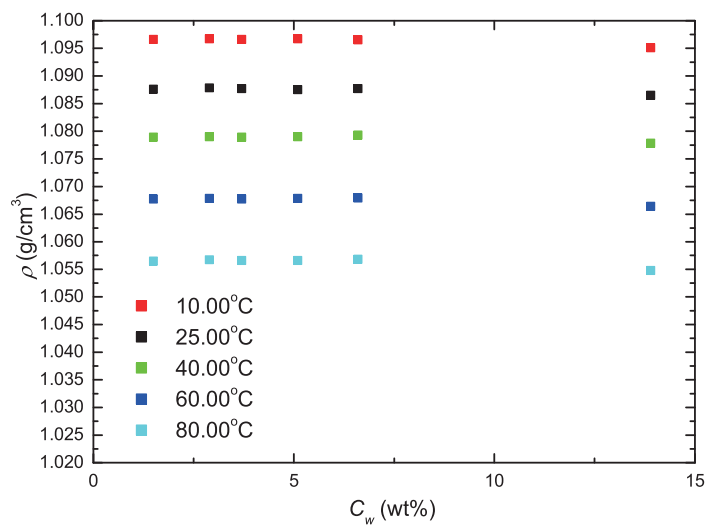

Fig. 4. Effect of water content on the density of pullulan/ $\mathrm{BmimCl}$ solutions at different temperatures.

\section{Conclusion}

In this study, pullulan was successfully dissolved into $\mathrm{BmimCl}$ and EmimAc without degradation. The densities of these pullulan/IL solutions were measured and empirical relationships were obtained to describe concentration and temperature effects on these densities. Using these results, the concentration $C$ in wt $\%$ could be converted into $c$ in $\mathrm{g} / \mathrm{cm}^{3}$. This will play an important role in future understanding of the pullulan/IL solutions used as standards for IL soluble polymers.

\section{References}

1) Ion Ekitai (Ionic liquids) II, ed. by H. Ohno, CMC Shuppan: Tokyo, (2006).

2) T. Welton, Chem. Rev., 99, 2071 (1999).

3) P. Kubisa, J. Polym. Sci. Part A: Polym. Chem., 43, 4675 (2005).

4) K. R. Seddon and A. Stark, M. J. Torres, Pure. Appl. Chem.72, 2275-2287 (2000).

5) Q. Yang, H. Zhang, B. Su, Y. Yang, Q. Ren, and H. Xing, J. Chem. Eng. Data, 55, 1750 (2010).

6) J. H. Poplin, R. P. Swatloski, J. D. Holbrey, S. K. Spear, A. Metlen, M. Gratzel, M. K. Nazeeruddin, and R. D. Rogers, ChemCommun (UK), 20, 2025 (2007).

7) J. Wu, J. Zhang, H. Zhang, J. He, Q. Ren, and M. Guo, Biomacromolecules, 5, 266 (2005).

8) J. Lu and F. Yan, J. Texter, Prog. Polym. Sci., 34, 431 (2009).

9) R. P. Swatloski, S. K. Spear, J. D. Holbrey, and R. D. Rogers, J. Am. Chem. Soc., 124, 4974 (2002).

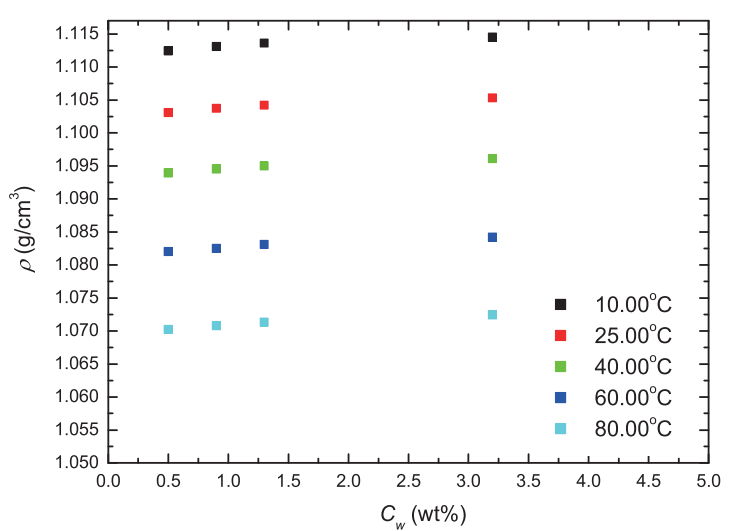

Fig. 5 Effect of water content on the density of pullulan/EmimAc solutions at different temperatures.

10) $\mathrm{H}$. Zhang and J. Wu, J. Zhang, J. He, Macromolecules, 38, 8272 (2005).

11) B. Kosan, C. Michels, and F. Meister, Cellulose, 15, 59 (2008).

12) M. B. Turner, S. K. Spear, J. D. Holbrey, and R. D. Rogers, Biomacromolecules, 5, 1379 (2004).

13) S. Shang, L. Zhu, and J. Fan, Carbohydrate Polymers, 86, 462 (2011).

14) Q. L. Kuang, J. C. Zhao, Y. H. Niu, J. Zhang, and Z. G. Wang, J. Phys. Chem. B, 112, 10234 (2008).

15) X. Chen, Y. Zhang, L. Y. Cheng, and H. P. Wang, $J$. Polym. Environ, 17, 273 (2009).

16) B. Kosan, K. Schwikal, and F. Meister, Cellulose, 17, 495 (2010).

17) M. Gericke, K. Schlufter, T. Liebert, T. Heinze, and T. Budtova, Biomacromolecules, 10, 1188 (2009).

18) T. Kato, T. Okamoto, T. Tokuya, and A. Takahashi, Biopolymers, 21, 1623 (1982).

19) K. Kawahara, K. Ohta, H. Miyamoto, and S. Nakamura, Carbohydr. Polym., 4, 335 (1984).

20) K. Nishinari, K. Kohyama, P. A. Williams, G. O. Phillips, W. Burchard, and K. Ogino, Macromolecules, 24, 5590 (1991).

21) O. Yamamuro, Y. Minamimoto, Y. Inamura, $S$. Hayashi, and H. Hamaguchi, Chem. Phys. Lett., 423, 371 (2006).

22) M. Kamo, Solution property of pullulan ionic liquid solution, Master thesis, Department of Molecular \& Material Sciences, Interdisciplinary Graduate School of Engineering Sciences, Kyushu University (2009). 
Appendix: Tables for row data.

Table A1. Densities $\rho$ of pullulan/BmimCl solutions between 10 and $80{ }^{\circ} \mathrm{C}$.

\begin{tabular}{|c|c|c|c|c|c|c|c|c|c|}
\hline \multirow[b]{2}{*}{$C(\mathrm{wt} \%)$} & \multicolumn{8}{|c|}{$\rho \mathrm{g} / \mathrm{cm}^{3}$} & \multirow[b]{2}{*}{$80.00^{\circ} \mathrm{C}$} \\
\hline & $10.00^{\circ} \mathrm{C}$ & $25.00^{\circ} \mathrm{C}$ & $30.00^{\circ} \mathrm{C}$ & $35.00^{\circ} \mathrm{C}$ & $40.00^{\circ} \mathrm{C}$ & $50.00^{\circ} \mathrm{C}$ & $60.00^{\circ} \mathrm{C}$ & $70.00^{\circ} \mathrm{C}$ & \\
\hline 0.00 & 1.0923 & 1.0836 & 1.0807 & 1.0778 & 1.0747 & 1.0687 & 1.0631 & 1.0575 & 1.0520 \\
\hline 0.55 & 1.0942 & 1.0855 & 1.0826 & 1.0796 & 1.0764 & 1.0707 & 1.0651 & 1.0595 & 1.0540 \\
\hline 1.01 & 1.0958 & 1.0871 & 1.0841 & 1.0811 & 1.0779 & 1.0723 & 1.0668 & 1.0612 & 1.0557 \\
\hline 2.26 & 1.0999 & 1.0912 & 1.0882 & 1.0852 & 1.0820 & 1.0764 & 1.0709 & 1.0654 & 1.0599 \\
\hline 4.02 & 1.1052 & 1.0965 & 1.0936 & 1.0907 & 1.0876 & 1.0818 & 1.0762 & 1.0707 & 1.0652 \\
\hline 5.71 & 1.1107 & 1.1021 & 1.0992 & 1.0963 & 1.0934 & 1.0873 & 1.0818 & 1.0763 & 1.0708 \\
\hline 9.77 & 1.1239 & 1.1153 & 1.1124 & 1.1096 & 1.1067 & 1.1009 & 1.0949 & 1.0894 & 1.0839 \\
\hline 16.22 & 1.1453 & 1.1368 & 1.1339 & 1.1311 & 1.1283 & 1.1226 & 1.1170 & 1.1112 & 1.1054 \\
\hline
\end{tabular}

Table A2. Densities $\rho$ of pullulan/EmimAc solutions between 10 and $80{ }^{\circ} \mathrm{C}$.

\begin{tabular}{cccccccccc}
\hline & \multicolumn{7}{c}{$\rho \mathrm{g} / \mathrm{cm}^{3}$} \\
\cline { 2 - 10 }$C(\mathrm{wt} \%)$ & $10.00^{\circ} \mathrm{C}$ & $25.00{ }^{\circ} \mathrm{C}$ & $30.00{ }^{\circ} \mathrm{C}$ & $35.00{ }^{\circ} \mathrm{C}$ & $40.00{ }^{\circ} \mathrm{C}$ & $50.00{ }^{\circ} \mathrm{C}$ & $60.00{ }^{\circ} \mathrm{C}$ & $70.00^{\circ} \mathrm{C}$ & $80.00{ }^{\circ} \mathrm{C}$ \\
0.00 & 1.1087 & 1.0994 & 1.0964 & 1.0934 & 1.0903 & 1.0843 & 1.0783 & 1.0724 & 1.0665 \\
0.54 & 1.1095 & 1.1001 & 1.0971 & 1.0941 & 1.0911 & 1.0851 & 1.0791 & 1.0732 & 1.0673 \\
0.97 & 1.1107 & 1.1013 & 1.0983 & 1.0953 & 1.0923 & 1.0863 & 1.0803 & 1.0744 & 1.0685 \\
1.65 & 1.1124 & 1.1031 & 1.1000 & 1.0969 & 1.0939 & 1.0880 & 1.0820 & 1.0761 & 1.0702 \\
3.05 & 1.1171 & 1.1079 & 1.1048 & 1.1018 & 1.0987 & 1.0926 & 1.0866 & 1.0808 & 1.0749 \\
4.85 & 1.1255 & 1.1163 & 1.1132 & 1.1102 & 1.1072 & 1.1012 & 1.0952 & 1.0892 & 1.0833 \\
7.13 & 1.1346 & 1.1248 & 1.1218 & 1.1188 & 1.1158 & 1.1098 & 1.1038 & 1.0979 & 1.0920 \\
9.70 & 1.1404 & 1.1305 & 1.1274 & 1.1244 & 1.1214 & 1.1154 & 1.1095 & 1.1036 & 1.0977 \\
16.50 & 1.1648 & 1.1556 & 1.1525 & 1.1495 & 1.1464 & 1.1402 & 1.1330 & 1.1281 & 1.1222
\end{tabular}

Table A3. Densities of a pullulan/BmimCl solution (1.35 wt \%) at different $C_{w}$ values between 10 and $80^{\circ} \mathrm{C}$.

\begin{tabular}{ccccccc}
\hline$T$ & \multicolumn{5}{c}{$\rho \mathrm{g} / \mathrm{cm}^{3}$} \\
$10.00{ }^{\circ} \mathrm{C}$ & 1.0966 & 1.0967 & 1.0966 & 1.0967 & 1.0965 & 1.0951 \\
\cline { 2 - 7 } $25.00^{\circ} \mathrm{C}$ & 1.0876 & 1.0878 & 1.0877 & 1.0875 & 1.0877 & 1.0865 \\
$40.00{ }^{\circ} \mathrm{C}$ & 1.0789 & 1.0790 & 1.0789 & 1.0790 & 1.0793 & 1.0778 \\
$60.00{ }^{\circ} \mathrm{C}$ & 1.0677 & 1.0678 & 1.0677 & 1.0678 & 1.0679 & 1.0664 \\
$80.00{ }^{\circ} \mathrm{C}$ & 1.0565 & 1.0567 & 1.0566 & 1.0566 & 1.0568 & 1.0548
\end{tabular}


Table A4. Densities of pullulan/EmimAc solution $(1.65 \mathrm{wt} \%)$ at different $C_{w}$ values between 10 and $80^{\circ} \mathrm{C}$.

\begin{tabular}{ccccc}
\hline & \multicolumn{4}{c}{$\rho \mathrm{g} / \mathrm{cm}^{3}$} \\
\cline { 2 - 5 } $10.00^{\circ} \mathrm{C}$ & 1.1124 & $\boldsymbol{C}_{\boldsymbol{w}}: 0.9 \mathrm{wt} \%$ & $\boldsymbol{C}_{\boldsymbol{w}}: 1.3 \mathrm{wt} \%$ & $\boldsymbol{C}_{\boldsymbol{w}}: 3.2 \mathrm{wt} \%$ \\
$25.00^{\circ} \mathrm{C}$ & 1.1031 & 1.1131 & 1.1136 & 1.1145 \\
$40.00^{\circ} \mathrm{C}$ & 1.0939 & 1.1037 & 1.1042 & 1.1053 \\
$60.00^{\circ} \mathrm{C}$ & 1.0820 & 1.0945 & 1.0950 & 1.0961 \\
$80.00^{\circ} \mathrm{C}$ & 1.0702 & 1.0825 & 1.0831 & 1.0842 \\
& 1.0708 & 1.0713 & 1.0724
\end{tabular}

